\title{
The Impact of Emotional Intelligence on Performance: A Closer Look at Individual and Environmental Factors
}

\author{
Khai The NGUYEN ${ }^{1}$, Tuyet Minh DUONG ${ }^{2}$, Nhi Yen TRAN ${ }^{3}$, Anh Thao HA ${ }^{4}$, Y. Nhu Thi PHUNG ${ }^{5}$
}

Received: October 02, 2019 Revised: November 01, 2019 Accepted: November 15, 2019

\begin{abstract}
This study presents a more comprehensive approach to investigate how Emotional Intelligence (EI) is associated with performance. Previous research has revealed that EI is related to positive outcomes such as better performance, life satisfaction and career success. However, in most research of EI, this factor has been investigated independently from the effect of contextual factors and other individual characteristics. This study extended the research on the impact of EI on student performance by simultaneously examining the impact of EI, individual factors - (1) Perseverance of Effort, (2) Goal Consistency and (3) Goal Clarity and learning environment factors - Program Fit in one study. The results based on the data collected from 1,117 students in Vietnam largely support the hypothesis that that EI was an important but not the only factor affecting the student performance. MANOVA and post-hoc analysis indicated that both individual and environmental factors better predicted performance than EI could. These results suggest that the impact of EI on individual performance is more complicated than what we have already known. Future study is encouraged to investigate both the mechanism through which EI impact individual performance and the interaction between EI and other factors that moderate the EI - performance relationship.
\end{abstract}

Keywords : Emotional Intelligence, Performance, Perseverance, Goal Consistency, Goal Clarity

JEL Classification Code : M10, M12, I20, I21

\section{Introduction}

The concept of Emotional Intelligence refers to "an ability

1 First Author and Corresponding Author, Head, Human Resource Management Program, Faculty of Business Administration, Ho Chi Minh City Open University, Vietnam. [Postal Address: 97 Vo Van Tan Street, District 3, Ho Chi Minh City, 700000, Vietnam] Email: khai.nt@ou.edu.vn

2 Research Assistant, Faculty of Business Administration, Ho Chi Minh City Open University, Vietnam.

Email: 1654010567tuyet@ou.edu.vn

3 Research Assistant, Faculty of Business Administration, Ho Chi Minh City Open University, Vietnam. Email: 1654010338nhi@ou.edu.vn

4 Research Assistant, Faculty of Business Administration, Ho Chi Minh City Open University, Vietnam. Email: 1654010008anh@ou.edu.vn

5 Research Assistant, Faculty of Business Administration, Ho Chi Minh City Open University, Vietnam. Email:1654010645y@ou.edu.vn

(c) Copyright: Korean Distribution Science Association (KODISA) This is an Open Access article distributed under the terms of the Creative Commons Attribution Non-Commercial License (http://Creativecommons.org/licenses/by-nc/4.0/) which permits unrestricted noncommercial use, distribution, and reproduction in any medium, provided the original work is properly cited. to perceive and express emotion, assimilate emotion in thought, understand and reason with emotion, and regulate emotion in the self and others" (Mayer, Salovey, \& Caruso, 2000, p. 396). Since the first time introduced by Salovey and Mayer (1990), EI has gained wide attention in the field of psychology. Recent studies have shown a positive relationship between EI and performance such as job performance, leadership, stress, better health, and well-being (Keefer, Parker, \& Saklofske, 2018). Individuals with high EI have the ability of self-regulation and self-motivation to promote performance, improve interpersonal relationships, and are often considered more affectionate by their peers.

In educational environment, student achievement not only assesses the student's academic ability but also the top concerns of universities (Nelson, Quinn, Marrington, \& Clarke, 2012; Severiens, Wolff, \& Herpen, 2015). Besides the close relationship between EI and student performance that has been explored in several studies, other personal factors such as intelligence (Minnaert \& Janssen, 1998), personality (Trapmann, Hell, Hirn, \& Schuler, 2007; Zimmerman, 2008), and self-efficacy (Chemers, Hu, \& 
Garcia, 2001) have been found to positively predict student performance. Most research on student academic achievement emphasized the impact of individual capacity (i.e. emotional intelligence or intelligence) or individual perception of their capacity (i.e. self-efficacy) but the impact of how a student's perception of future (e.g. goals) or perception of learning environment (e.g. fit with study program) is still not adequately addressed. From the perspective of higher education, this gap is particularly relevant because it not only focuses on individuals but also on the characteristics of the learning environment. The research of success in the past 10 years has found different conclusions about the role of personal factors for success in life. Specifically, Duckworth and Quinn (2009) confirm the importance of perseverance (grit) above factors such as IQ and EQ. Anderson and Strich (2015) affirm the positive impact of a clear goal on the level of work completion. In addition, the fit between an individual's ability and personjob fit ability has proven to be a key factor to success (Kristof-Brown, Zimmerman, \& Johnson, 2005).

Understanding the impacts of both personal and environmental factors on student academic achievements allows educators and managers to facilitate learning environment in accordance with individual personal characteristics instead of using a common solution for all students to achieve the best academic results (Vermunt, Richardson, Donche \& Gijbels, 2014). In addition, simultaneously examining personal characteristics and context factors is important not only for predicting academic success but also for understanding and explaining the mechanism of impact of these two factors on student learning results (Dart 1994; Donche \& Gijbels 2013; Kyndt, Raes, Lismont, \& Timmers, 2014; Vermunt \& Endedijk, 2011). Therefore, this study extends previous studies through an analysis of the combined effects of EI, the perception of student about the learning environment (e.g. Program Fit) and the factors of individuality including (1) Perseverance of Effort, (2) Goal Consistency and (3) Goals Clarity. Based on Person-environment fit theory of Edwards (1991) and the strong similarity between work and scholarship (Tynjälä, 2008), we argue the nature of the environment is not as important as whether or not the individual feels compatible with the environment Therefore, we decided to analyze the subjective fit that reflects the extent to which a student perceive he or she fits with the study program. This study enriches the trend of EI research by considering EI, personal and environmental factors in the same model. Research results help students better understand the factors affecting academic achievement, thereby proposing recommendations to improve the academic achievement of students.

\section{Theoretical Foundation}

\subsection{Emotionality}

Salovey and Mayer (1990) suggested that understanding can be a central feature of emotional intelligence behavior. They defined understanding as the ability to understand the emotions of others and to experience it again. Plutchik (1987) believed that understanding is not a separate emotion, but a kind of induction process whereby emotions, both positive and negative, are shared and increase the opportunity to act. In this way, understanding serves to bring people together. Mayer, Salovey and Caruso (2004) then defined EI as the ability to explain emotions to enhance thinking ability. It includes feeling emotions correctly, approaching and creating emotions to support thinking, understanding emotions and knowledge of emotions, and to regulate emotions to promote emotional development and intellectual growth.

\subsection{Self-control}

The controlled view, conscious of self-regulation is one of the terms that refers to self-control, called "will", best expressed when behavior is altered (Carver \& Scheier, 2011). Specifically, self-control refers to conscious, deliberate and effortful processes, such as resisting temptation and controlling one's emotions through which to regulate behavior towards achieving certain objectives or standards.

Self-control is also defined as the ability to delay immediate satisfaction of smaller rewards for greater rewards later (Ainslie, 1975; Mischel, Shoda, \& Rodriguez, 1989; Kirby \& Herrnstein, 1995). This definition includes the concept of inhibition efforts, but is expanded in the sense that it emphasizes the dilemma of self-control or conflict between a short-term, immediate, pleasurable choice (need to be depressed) and a long-term option with greater rewards than value. The ability to give up immediate rewards reflects self-control. Research by Duckworth and Seligman (2007) shows that self-discipline plays a greater role in academic success than IQ. In their study, they observed that students with better self-control to go to better schools, have higher grades and better test scores.

\subsection{Well-being}

Well-being is assessed according to the general point of view: Satisfaction with social support, quality of life related to health, satisfaction with life and impact on life. Wellbeing is a multi-dimensional phenomenon, integrating biological, psychological, social and spiritual dimensions (Cloninger, 2004, 2006a, 2006b; Bartels \& Boomsma, 2009; McDowell, 2010). Well-being refers to the emotional and cognitive aspects of subjective experience due to personal evaluation of some aspects of life (Keyes, Shmotkin \& Ryff, 2002; Huppert \& Whittington, 2003). Hedonic refers to the emotional aspects of individual's positive life experience (Diener, 1984), including no negative emotions, the presence of positive emotions, the satisfaction of life and the social participation (Ryan \& Deci, 2001). Well-being refers 
to the harmony between personal goals and values and life experiences (Ryff, Singer, \& Love, 2004), and is related to the personal development of individuals (Ryan \& Deci, 2001).

\subsection{Social Skills}

Socia skills is related to interpersonal interactions, and includes sensory, cognitive and motor skills (Jarkowski, 2011). In general, social skills represent what skills and knowledge combine and include cognitive and social abilities (Dewe, 2001). According to Deniz (2002) people interact with their environment by developing social relationships. In the process of interaction, people can only develop strong relationships by acquiring adequate social skills.

\subsection{Grit}

Grit is a personal strength defined by the following aspects: Perseverance of effort and Consistency of interest (Duckworth, Peterson, Matthews, \& Kelly, 2007). Perseverance of effort demonstrates sustainability for longterm goals despite failure. Consistency of interest represents passion and dedicated time, attention and commitment to long-term goals.

\subsection{Goals Clarity}

According to the theory of goals clarity, individuals perform better if the job guidance objectives are clear, specific and challenging instead of vague and unbound (Latham, Borgogni \& Petitta, 2008; Latham \& Locke, 2013; Rainey \& Jung, 2015). This theory proposes four distinct motivational mechanisms: orientation, effort, persistence and strategy (Latham \& Locke, 1991, 2013). Goals clarity helps individuals know what is expected of them and what behavior is functional to achieve their goals, reduce ambiguity about roles (Davis \& Stazyk, 2015; Pandey \& Wright, 2006). If they believe in a person's ability to be strong and ambiguous about their roles, they can achieve higher performance (Bandura, 2013; Davis \& Stazyk, 2015; House \& Rizzo, 1972; Pandey \& Rainey, 2006). Research has shown that these mechanisms and the effectiveness of setting goals also apply to group levels in the health and private sectors (Hoegl \& Parboteeah, 2003; West \& Anderson, 1996).

\subsection{Person-Environment Fit - P-EF}

Person - environment Fit - P-EF defines relevance as the similarity between personal factors (personal ability) and situational factors (job requirements) that lead to positive outcomes such as satisfaction, performance and commitment (Edwards and Shipp, 2007). In the context of higher education, the P-EF suitability study mainly focused on
Interest-major Fit (Schmitt, Realo, Voracek \& Allik, 2008; Tracey \& Robbins, 2006; Wessel, Ryan \& Oswald, 2008), specifically the relevance of the personal interests and disciplines that students are studying. Some studies have found that Interest-major Fit predicts academic achievement (Etzel \& Nagy 2016).

\subsection{Studying Performance}

Kuncel, Hezlett and Ones (2004)'s study showed that study performance in the classroom is the final product of many different behaviors. Study performance is a concept that is often understood by many different concepts in practice as well as in science, with many views of approaching study performance of students around the world in general and Vietnamese students in particular. Study performance is an acquired knowledge or skills developed in school subjects are often designed with test scores or grades taught by teachers" (Good, 1959).

Academic achievement is measured on the cumulative average of the different subjects that belong to students who are studying from the second year at the university and do not represent intelligence. It represents the ability or level of competence in the school measured by tests and presented in a class based on student achievement. Richardson, Abraham and Bond, (2012) point out that psychology of individual differences appears in the effort to predict academic performance. They claim that university students' performance is often expressed by grade point average (GPA). GPA is a measurement goal with good internal reliability and time stability, and therefore no other academic results compete for its measurement utilities (Plant, Ericsson, Hill, \& Asberg, 2005).

\subsection{Research Hypotheses}

\subsubsection{EI \& Student Performance}

Studies that explore the relationship between emotional intelligence and learning outcomes have resulted in mixed results. Schutte, Malouff, Hall, Haggerty, Copper, Golden and Dornheim (1998) found that emotional intelligence predicts a student's GPA. According to Rozell, Pettijohn, and Parker (2002), there is a small but meaningful relationship between academic success and emotional intelligence. Petrides, Frederickson and Furnham (2004) argue that emotional intelligence regulates the relationship between study performance and cognitive ability. Parker, Summerfeldt, Hogan, and Majeski (2004) show that highly successful students score higher than the unsuccessful group in three of the four factors (personal ability, stress management and adaptability) of emotional intelligence.

Nasir and Masur (2010) have confirmed that emotional intelligence significantly predicts learning outcomes among 132 students at various departments of International Islamic University, Islamabad (IIUI). Also in a previous study by Rozell et al. (2002), the result of a positive relationship 
between emotional intelligence and CGPA of Mid-Western University students is consistent with the notion that emotional intelligence contributes significantly to academic success.

\subsubsection{Grit \& Student Performance}

Duckworth and Seligman (2017) has shown that smart students alike succeed or fail for reasons completely separate from their innate ability to study. Why do some individuals complete more than others with the same intelligence? A personal quality shared by most successful and successful people is grit. Grit can be a quality that makes these highly successful individuals different from everyone else (Duckworth et al., 2007). Academic achievement is a success in the learning process at the students' lecture hall. The aforementioned arguments show that grit may be necessary such as IQ for students' high achievement in society.

\subsubsection{P-E Fit \& Student Performance}

Pittman and Richmond (2007) found that students feel fit with the curriculum predicting their GPA significantly even after controlling socioeconomic status, gender, and ethnicity and proficiency education of parents. Finally, the study of Ostrove and Long (2007) has shown that students with school suitability are significantly predicted by their social class, so higher class students have more university suitability.

\subsubsection{Goal Clarity \& Student Performance}

A research group on ambiguous goals in public organizations is based on the theory of goals clarity, showing that organizations face many difficulties and the employee performance decreases when setting unclear goals. (Chun \& Rainey, 2005; Davis \& Stazyk, 2015; Jung, 2011; Pandey \& Rainey, 2006; Rainey \& Jung, 2014; Wright, 2004). Goal-setting is an instrumental skill for achieving objectives and motivating behavior toward a performance standard (Locke \& Latham, 2002). Students who set higher academic goals tend to believe they have the capability to self-regulate toward it even in the long haul of a semester (Wolters, 2003; Zimmerman, 2008). A study from Knouse, Wu and Amon (2014) at a women's college showed that students who set clearer goals also have higher motivation for achieving these goals over the semester. Combining insights from these research streams shows the expectation that goals clarity will also impact student study performance.

From the above discussion, the main goals of the study are three-fold and corresponding with the three hypotheses:

First, we retest the impact of EI on student performance. For this objective, our first hypothesis is that we predict a positive relationship between EI and student performance.

Second, we test the impact of individual and environmental factors on student performance. For this objective, in the second hypothesis, we predict all positive relationships between (1) Perseverance of Effort, (2) Goal Consistency, (3) Goals Clarity, (4) Program Fit and student performance.

Last, we aim to explore the effectiveness of adding factors beyond the impacts of EI in explaining the variance of student performance. For this objective, we propose the third hypothesis that all the four factors including (1) Perseverance of Effort, (2) Goal Consistency, (3) Goals Clarity, and (4) Program Fit are at least, as effective as EI in predicting student performance.

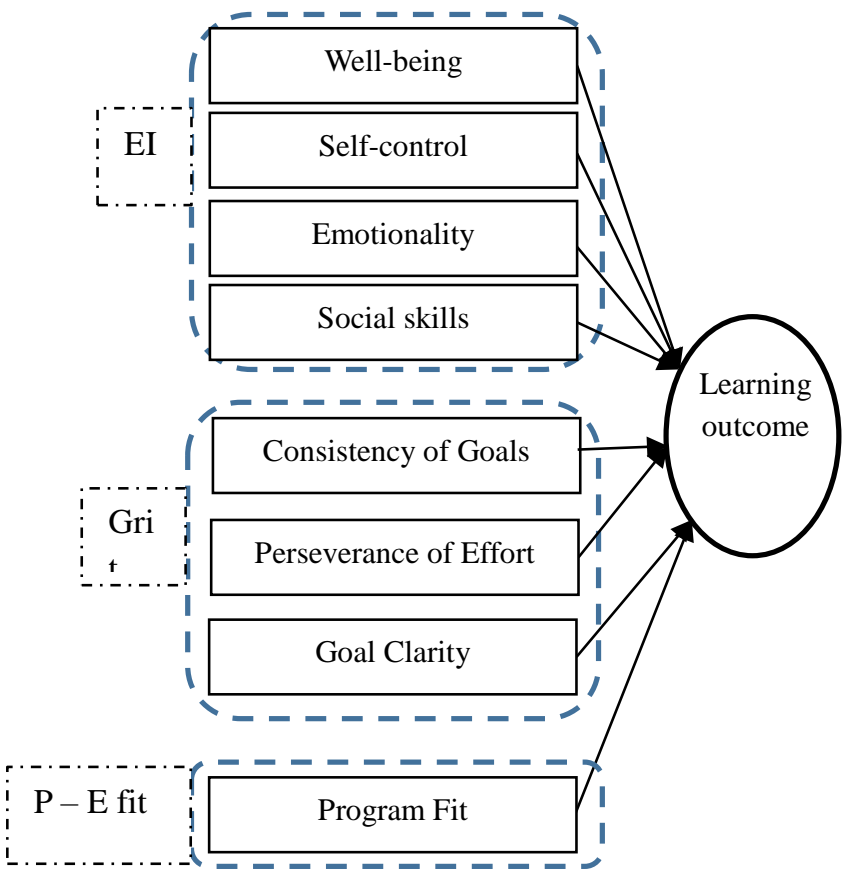

Figure 1: Research Model

\section{Methodology}

\subsection{Sample}

Survey forms are sent to university students in Ho Chi Minh City in a convenient way. The survey also clearly shows the purpose of the study and ensures that respondents' information is only used for research and confidentiality.

\subsection{Measures}

The scale in this study uses the 7-point Likert scale and the content of scales based on the theory of concepts in research models and study performance. Scale measuring well-being, self-control, emotionality, social skills using scale of Cooper, and Petrides (2010). The scale of Perseverance of Efforts, including 6 observed variables (Duckworth \& Quinn, 2009). The scale of Program Fit, including 5 observed variables (Edward, 1991). The scale of Consistency of Interests is based on the scale of Duckworth and Quinn (2009). The scale of Goals clarity utilizes 
Sawyer's (1992) with 5 observed variables.

The student study performance is obtained through the ranking system consisting of five levels: Weak, Average, Good, and Excellent and Distinction. In many universities in Vietnam, the final overall result reflected in the student record is the rank, not the GPA event a student's rank is determined by his or her GPA. A student can calculate the GPA by self but that GPA is not showed in the university's system. Therefore, we asked the students to report their rank in the university system, not the GPA calculated by self.

\section{Results}

\subsection{Preliminary Analysis}

Public schools accounted for $62.09 \%$, while private schools accounted for $37.91 \%$. Male sex groups accounted for $58.41 \%$ and females were $41.59 \%$. Since freshmen do not know the average point of the school year, so the study does not conduct surveys, the results show that the second year students group accounted for $40.81 \%$, the third year accounted for $43.33 \%$, the fourth year accounted for $15.86 \%$. The group of basic science accounted for $19.15 \%$, the group of applied science and technology accounted for $22.63 \%$, the economic sector accounted for $36.36 \%$, the social science group accounted for $21.86 \%$.

The ratio of study performance is distributed in 3 groups: average, good, excellent. In which the average group rate was $27.27 \%$, the good group was $61.70 \%$, the excellent group was $11.03 \%$. This shows that the average academic score of students is mostly good, followed by average, the excellent rate accounts for very little. We have checked the result with 5 universities and found that the total number of weak and distinction students just account for less than one percent of the total students. So, the data collected from the sample reflected the characteristic of the population.

\begin{tabular}{|c|c|c|c|}
\hline \multicolumn{2}{|c|}{ Sample $n=1.117$} & Frequency & $\%$ \\
\hline \multirow{2}{*}{$\begin{array}{ll}\begin{array}{l}\text { Type } \\
\text { school }\end{array} & \text { of } \\
\end{array}$} & Public & 693 & 62.04 \\
\hline & Private & 424 & 37.96 \\
\hline \multirow{4}{*}{ Sector } & Basic science & 212 & 18.98 \\
\hline & $\begin{array}{l}\text { Applied science - } \\
\text { Technology }\end{array}$ & 254 & 22.74 \\
\hline & Economics & 407 & 36.44 \\
\hline & Social science & 244 & 21.84 \\
\hline \multirow{2}{*}{ Gender } & Male & 654 & 58.55 \\
\hline & Female & 463 & 41.45 \\
\hline \multirow{3}{*}{$\begin{array}{l}\text { Length of } \\
\text { study }\end{array}$} & Year 2 & 456 & 40.82 \\
\hline & Year 3 & 486 & 43.51 \\
\hline & Year 4 & 175 & 15.67 \\
\hline \multirow{3}{*}{ GPA } & Average & 303 & 27.3 \\
\hline & Good & 691 & 61.6 \\
\hline & Excellent & 120 & 10.2 \\
\hline
\end{tabular}

\subsection{Measure Evaluation}

Table 2 shows means, standard deviations, Cronbach's $\alpha$, and correlations of the latent constructs in the measurement model. All factors have a Cronbach's $\alpha$ larger than 0.7; if skipping any observable variables in these factors, the alpha number will decrease. Meanwhile, the "Corrected Item-Total Correlation" in the scale are greater than 0.3 , so all observations are kept. Evaluating the correlation between variables by a Pearson test gave the results in Table 1: most independent variables correlate with the dependent variable at the $99 \%$ confidence level, with correlation coefficients $\geq$ 0.3 correlations between variables.

Table 2: Mean (M), Cronbach's a Testing Result, Standard Deviations (SD), and Intercorrelations of Study Variables

\begin{tabular}{|c|c|c|c|c|c|c|c|c|c|c|c|c|}
\hline \multicolumn{2}{|l|}{ Variable } & M & Cronbach's a & SD & 1 & 2 & 3 & 4 & 5 & 6 & 7 & 8 \\
\hline 2. Self-control & SC & 4.62 & 0.805 & 1.01 & $.59^{\star *}$ & 1 & & & & & & \\
\hline 3. Emotionality & EE & 4.96 & 0.793 & 0.87 & $.55^{\star *}$ & $.58^{* \star}$ & 1 & & & & & \\
\hline 4.Social skills & SS & 4.76 & 0.882 & 0.94 & $.63^{* *}$ & $.61^{* *}$ & $.75^{\star *}$ & 1 & & & & \\
\hline 6.Perseverance of Effort & $\mathrm{PE}$ & 4.65 & 0.827 & 1.00 & $.55^{\star *}$ & $.55^{\star *}$ & $.57^{\star *}$ & $.66^{\star \star}$ & $.13^{\star \star}$ & 1 & & \\
\hline 7.Goal Clarity & GC & 4.68 & 0.887 & 1.2 & $.51^{* *}$ & $.46^{* *}$ & $.50^{\star *}$ & $.58^{\star *}$ & $.17^{* *}$ & $.66^{* *}$ & 1 & \\
\hline 8.Program Fit & $\mathrm{PF}$ & 4.23 & 0.890 & 1.44 & $39^{\star *}$ & $.40^{* *}$ & $.41^{* *}$ & $.48^{\star *}$ & $.11^{* *}$ & $.55^{\star *}$ & $.62^{* \star}$ & 1 \\
\hline
\end{tabular}

Note: ${ }^{*}$ Significant level at $p<0.001,{ }^{* *}$ Significant level at $p<0.005$.

\subsection{Confirmatory Factor Analysis}

In this study, we performed a confirmatory factor analysis (CFA) through structural equation modeling (SEM) in AMOS 20. The CFA results show that the model has indicators revealing the suitability of the model with market information. Based on the Chi-square/df $=1.245(<3)$, RMSEA $=0.042(<0.08)$, GFI $=0.91, \mathrm{TLI}=0.92, \mathrm{CFI}=$ $0.901>0.9)$ are standard. This result indicates that the measurement model fits well with the data. Table 2 shows that the standardized weights of the scale are both high, higher than 0.5, and the p-value of each pair is lower than 0.05 . Moreover, the correlation coefficients together with the standard deviations show that they are different from 1 . Thus, the adjusted research model achieves convergence value and discriminating value. The model has no correlation among the measurement errors of the factor groups, so the model becomes monad.

\subsection{Hypothesis Testing}

The one-way Multivariate Analysis Of Variance test 
(MANOVA) was employed to determine whether the emotional intelligence and study environment of students are related to GPA. Bartlett Sphericity Test shows the assumption of multivariate normality was made and found significant $(3.144 .73 ; \mathrm{p}<.01)$, indicating that the MANOVA test can be applied to this research data. Besides, MANOVA is used when there is a lack of linear relationship between dependent variables. According to Leech, Barret and Morgan (2005), MANOVA is used when the dependent variables are theoretically related but if these variables have a relationship between variable dependent is too high (Correlation coefficients over .80 or .90 ), it will cause problems in MANOVA. Another assumption that must be provided for MANOVA is the lack of a multiple linear relationship between dependent variables. In order to use MANOVA, dependent variables must be related to each other theoretically (Leech et al., 2005). Table 2 shows that the relationship between dependent variables is lower than .80 , so the data is consistent with MANOVA.

Table 3: MANOVA Result

\begin{tabular}{|c|c|c|c|c|c|c|c|}
\hline \multirow{2}{*}{ Factors } & \multirow{2}{*}{ (I) GPA } & \multirow{2}{*}{ (J) GPA } & \multirow{2}{*}{ Mean Difference (I-J) } & \multirow{2}{*}{ Std. Error } & \multirow{2}{*}{ Sig. } & \multicolumn{2}{|c|}{ 95\% Confidence Interval } \\
\hline & & & & & & Lower Bound & Upper Bound \\
\hline Well-being & Average & Excellent & $-.3945^{\star}$ & .1315 & .008 & -.703 & -.086 \\
\hline Self-Control & Average & Excellent & $-.4567^{*}$ & .1232 & .001 & -.746 & -.168 \\
\hline \multirow{2}{*}{ Emotionality } & \multirow{2}{*}{ Average } & Good & $-.2087^{\star}$ & .0601 & .002 & -.35 & -.068 \\
\hline & & Excellent & $-.3540^{*}$ & .1064 & .003 & -.604 & -.104 \\
\hline \multirow{4}{*}{ Perseverance of Effort } & \multirow{2}{*}{ Average } & Good & $-.4722^{*}$ & .0684 & .001 & -.633 & -.312 \\
\hline & & Excellent & $-.5998^{\star}$ & .1215 & .001 & -.884 & -.316 \\
\hline & \multirow{2}{*}{ Good } & Average & $.4722^{*}$ & .068 & .002 & .3117 & .6326 \\
\hline & & Excellent & -0.128 & .1121 & .002 & -.391 & .1355 \\
\hline Program Fit & Average & Good & $-.4286^{\star}$ & .0994 & .002 & -.662 & -.195 \\
\hline \multirow{3}{*}{ Goal Clarity } & Average & Excellent & $-.8657^{\star}$ & .1443 & .001 & -1.204 & -.527 \\
\hline & \multirow{2}{*}{ Good } & Average & $.5223^{*}$ & .0816 & .001 & .331 & .7137 \\
\hline & & Excellent & $-.3434^{*}$ & .1338 & .028 & -.658 & -.029 \\
\hline
\end{tabular}

In this study, the significance level for the Box's M test was taken as .01. In the study, the significance value for the Box's $\mathrm{M}$ test calculated for the dependent variable data set consisting of independent variables shows that the assumption of homogeneity of the variance covariance matrices for the independent variables is met (frequency [Box's $M=201.645, p>.01]$ ). The Least Significant Difference (LSD) post hoc tests MANOVA to test the impact of 8 factors in the model are: (1) Well-being, (2) Self-control, (3) Emotionality, (4) Social skills, (5) Consistency of Interests, (6) Perseverance (7) Goals clarity, (8) Program Fit and the impact variable is the study performance of students with 3 values, average, good and excellent.

The statistical results show that the hypotheses are supported in a general way. This means that there are differences between students with different academic achievements in the elements of the research model. For example, a group of students with good academic performance will have an average value of the components of emotional intelligence and the other factors differ from the average of these factors from excellent students.

According to Tukey analysis results (Table 3), there is a statistically significant difference between the groups of factors because of the significance level observed in the test of the average difference pair $<0.05$. The analytical results show that all factors are able to distinguish between different learning outcomes groups. According to the results of the study, the factors that make up EI include: wellbeing, self-control, understanding and social skills that influence different learning outcomes. In particular, the elements of EI are only valuable to distinguish between students with average GPA with good and excellent.

The results of analysis of persistence impact on students' study performance showed that: Consistency of Interest (CI) is not worth distinguishing between student groups. Meanwhile, the Persistence of Effort (PE) is capable of distinguishing between groups of students with academic achievement in all three groups. Specifically, the group of students with average learning results has less perseverance than the group of students with good academic results of $0.47(\mathrm{p}<.01)$ and lower than the group of students with excellent academic results of 0.59 ( $\mathrm{p}<.01)$, the good student group has a higher discrimination value than the average student group of $.47(\mathrm{p}<.05)$ and a lower than excellent 
student of .128 ( $\mathrm{p}<.05)$.

The analysis results of impacts of learning environment on study performance of students show that: the factor of program fit is valuable to distinguish between the study performance of students. The group of average students is lower than the group of good students of $0.43(\mathrm{p}<.01)$ and lower than the group of excellent students with excellent is 0.699 ( $\mathrm{p}<.05)$. The group of students with good academic results than students with average learning results of $.43(\mathrm{p}$ $<0.01$ ) and lower than good students is .27 ( $\mathrm{p}<.05$ ). Goals clarity is the most powerful factor in student achievement. In particular, the group of students with excellent academic results has a higher average value of goal clarity than the group of students with an average learning result of 0.20 (p $<.05$ ) and a group of students with good results academic performance is higher than that of students with an average learning result of 0.17 ( $\mathrm{p}<.05$ ). Thus, it can be concluded that learning outcomes differ between the impact factors and the assumptions are supported. Especially environmental factors have a degree of distinction between groups of students with different learning outcomes.

\section{Discussion}

This research result is in line with research of EI impact on student performance (Matthews, Roberts, \& Zeidner, 2004, Leedy \& Ormrod, 2005; Vela, 2003). Specifically, this study sought to determine if the 4 factors under examination have the ability to predict student performance. Similar methodology has been employed in other studies regarding EI and academic achievement by Woitaszewski and Aalsma (2004), and El Anzi (2005). Perera and DiGiacomo (2015) demonstrated that relationship between the EI and student performance was significant, however, in an indirect relationship. However, the impact of the 4 EI factors on student performance was not as strong as the other factors in the research model. Specifically, 4 components of EI are only valuable to distinguish between average and good and excellent students.

Meanwhile, PE, GC, PF are valuable to distinguish between average students with good and excellent students and good students with average and excellent students. This shows that the impact of EI to student performance is not as strong as the student learning environment factors. Further, the most important thing in this research result is the impact in terms of circumstances and grit has a stronger impact on EI in determining performance of student. This may be because the student's EI has an initial basis of education and nurturing in the family but the degree of impact on academic success depends on the conditions of learning and communication in the different study environment. On the other hand, study of Gilani, Waheed, Saleem and Shaukat (2015) conducted a research on Pakistani university students and result showed that relationship between EI and student success was negatively insignificant. According to Shipley, Jackson, and Segrest (2010) trait emotional intelligence has no significant association with GPA. Therefore, in the future, studies should learn more about the impact of EI on GPA in different contexts to clarify the importance of EI to the work and study success of individuals.

Besides, the study also examined the relationship between emotional intelligence and learning environment to students' learning outcomes. As a result, emotional intelligence factors and learning environments that have a positive relationship to student study performance are SC, EE, SS, PE, GC and PF. In other words, students with good emotional intelligence, persistent pursuit of goals and relevance to the curriculum often have better academic results. This result supports previous studies of students with perseverance and effort that will outperform those with lower PE (Bardwell \& Braaksma 1985; Stober \& Rambow, 2007).

The relationship between GC and PF to GPA is similar to previous studies on goal-setting improving college performance (Bembenutty, 2009; Knouse et al., 2014). Students will set up their own effective learning strategies / plans if they feel they are fit for the curriculum and have a clear goal to strive for. In particular, PF is the most important because students will learn better when the curriculum is suitable for their intellectual and physical abilities as well as family and social circumstances (Pittman \& Richmond, 2007)

In the present study, there were no relationship observed between CI and GPA. This result is in contrast to the previous research (Duckworth et al., 2007). This topic would be a good area for further study. Bazelais, David John and Doleck (2016) also points out that CI is not a positive influence on academic performance, and Stewart's (2015) research found no relationship between CI and GPA of freshman. This indicates that CI plays a minor role in the performance of university students.

\section{Conclusions}

The study shows the impact of the factors EI, grit, PE fit to student performance: (1) emotionality, (2) self-control, (3) social skills, (4) perseverance, (5) program fit, (6) goals clarity. However, EI factors do not show strong distinction between student groups such as grit and P-E elements. Analyzing the emotional intelligence of students, persistence as well as the learning environment shows that the assessment level of components of emotional intelligence, persistence and environmental factors is not high, most of the assessment has not reached level 5 (agreed level). This shows that schools, teachers as well as students still have chance to improve their emotional intelligence, grit and perception of fit. Students should set detailed short-term goals to easily achieve long-term goals. On the school side, it is recommended to organize soft skill classes such as selfidentification skills, goal-setting skills, time management skills to help students understand their own strengths and weaknesses, and able to set suitable goals and achieve that 
goal effectively, these skills classes help students learn how to solve problems in life and learning.

Our study holds both strengths and limitations as well. The first strength lies in large sample size from ten universities that support the generalizability of the findings. Moreover, we collected the objective data for the outcome variables that helps reduce common method variance. There are also some limitations to be declared. First, the study used cross sectional for the antecedent variables that may cause some common methods mistake, thus reducing the validity of the research conclusion. Second, the range of the outcome variable was restricted so that the conclusion could not be found for the remaining question: Does EI and other factors impact the stud performance of distinction and weak students?

Future studies in this area should focus on the flexibility of the environment, grit, such as seeking to increase this orientation or the motivation style that can serve to improve performance in other areas. Each other (business, service, education, etc.), especially in the field of EI, plays an important role such as teachers, nurses, or industries with a great deal of communication between people. It is necessary to have an objective measurement performance or result. It is also essential to consider the impact of these factors not only on individual performance but also on the interaction between these factors.

\section{References}

Ainslie, G. (1975). Specious reward: A behavioral theory of impulsiveness and impulse control. Psychological Bulletin, 82(4), 463-496. Doi:10.1037/h0076860.

Andrew, R. (2011). Introducing ANOVA and ANCOVA. London, UK: Sage.

Anderson, D. M., \& Stritch, J. M. (2015). Goal clarity, task significance, and performance: Evidence from a laboratory experiment. Journal of Public Administration Research and Theory. 26(2), 211-225. https://doi.org/10.1093/jopart/muv019.

Bandura, A. (2013). The role of self-efficacy in goal-based motivation. In E. A. Locke, \& G. P Latham (Ed.), Development in goal setting and task performance (pp.147-157), New York: Taylor \& Francis.

Bardwell, R., \& Braaksma, E. F. (1985). Motivation as a multifactor trait. The Journal of Psychology, 119, 5-14. DOI: 10.1080/00223980.1985.9712601.

Bartels, M., \& Boomsma, D. I. (2009) Born to be happy? The etiology of subjective well-being. Behaviour Genet, 39(6), 605-615. doi: 10.1007/s10519-009-9294-8.

Bazelais, P., David, J. L., \& Doleck, T. (2016). How does grit impact college students' academic achievement in science? European Journal of Science and Mathematics Education, 4(1), 33-43.

Bembenutty, H. (2009). Academic delay of gratification, self-efficacy, and time management among academically unprepared college students. Psychological Reports,
104(2), 613-623. https://doi.org/10.2466/pr0.104.2.613623.

Carver, C. S., \& Scheier, M. F. (2011). Self-regulation of action and affect. In Vohs, K. D., \& Baumeister, R. F. (Eds.), Handbook of self-regulation: Research, theory, and applications (2nd ed.) (pp.3-21), New York: Guilford.

Chemers, M. M., Hu, L., \& Garcia, B. F. (2001). Academic self-efficacy and first-year college student performance and adjustment. Journal of Educational Psychology, 93(1), 55-64. DOI: 10.1037/0022-0663.93.1.55.

Chun, Y. H., \& Rainey, H. G. (2005). Goal ambiguity and organizational performance in U.S. federal agencies. Journal of Public Administration Research and Theory, 15(4), 529 - 557. https://doi.org/10.1093/jopart/mui030.

Cloninger, C. R. (2004). Feeling good: The science of wellbeing. New York, NY: Oxford University Press.

Cloninger, C. R. (2006a). Personality as a dynamic psychobiological system, in Dimensional Models of Personality Disorders: Refining the Research Agenda for $D S M$-V. In T. A. Widiger, E. Simonsen, P. J. Sirovatka, \& D. A. Regier (eds.) (pp.73-76), Washington, DC: American Psychiatric Press.

Cloninger, C. R. (2006b). The science of well-being: An integrated approach to mental health and its disorders. World Psychiatry, 5, 71-76.

Cooper, A., \& Petrides, K. V. (2010). A psychometric analysis of the Trait Emotional Intelligence Questionnaire-Short Form (TEIQue-SF) using item response theory. Journal of Personality Assessment, 92(5), 449-457. doi:10.1080/00223891.2010.497426.

Dart, B. C. (1994). A goal-mediational model of personal and environmental influences on tertiary students' learning strategy use. Higher Education, 28, 453-470. doi: 10.1007/bf01383937.

Davis, R. S., \& Stazyk, E. C. (2015). Developing and testing a new goal taxonomy: Accounting for the complexity of ambiguity and political support. Journal of Public Administration Research and Theory, 25, 751-775. DOI: 10.1093/jopart/muu015.

Deniz, M. E. (2002). Investigation of decision making strategies and social skills levels of university students with respect to TA-dominant ego states and some personal characteristics. Unpublished PhD Dissertation. Konya: Selcuk University. DOI: 10.9734/BJESBS/2015/16123.

Dewe, P. J. (2001). Work stress, coping and well being: Implementing strategies to better understand the relationship. In L. P. Pamela, \& C. G. Daniel (ed.), Exploring theoretical mechanisms and perspectives: Research in occupational stress and well-being (pp.6396), Emerald Group Publishing Limited. Doi:10.1016/S1479-3555\%2801\%2901010-1.

Diener, E. (1984). Subjective well-being. Psychological Bulletin, 95, 542-575. doi:10.1037/0033-2909.95.3.542.

Donche, V., \& Gijbels, D. (2013). Understanding learning pattern development in higher education: A matter of 
time, context and measurement. Studies in Educational Evaluation, $39(1), \quad 1-3 . \quad$ DOI: 10.1016/j.stueduc.2012.11.002.

Duckworth, A. L., \& Quinn, P. D. (2009). Development and validation of the Short Grit Scale (GRIT-S). Journal of Personality Assessment, 91(2), 166-174.

Duckworth, A. L., \& Seligman, M. E. (2017). The science and practice of self control. Psychological Science, 12(5), 715-718.

Duckworth, A. L., \& Seligman, M. E. P. (2005). Selfdiscipline outdoes IQ in predicting academic performance of adolescents. Psychological Science, 16, 939-944. doi:10.1111/j.1467-9280.2005.01641.x.

Duckworth, A. L., \& Seligman, M. E. (2007). Self-discipline outdoes IQ in predicting academic performance of adolescents. Psychological Science, 16(12), 939-44. https://doi.org/10.1177/1745691617690880.

Duckworth, A. L., Peterson, C., Matthews, M. D., \& Kelly, D. R. (2007). Grit: Perseverance and passion for longterm goals. Journal of Personality and Social Psychology, 92(6), 1087-1101. http://dx.doi.org/10.1037/0022-3514.92.6.1087.

Edwards, J. R. (1991). Person-job fit: A conceptual integration, literature review, and methodological critique. Oxford, England: John Wiley \& Sons.

Edwards, J. R., \& Shipp, A. J. (2007). The relationship between person-environment fit and outcomes: An integrative theoretical framework. In C. Ostroff, \& T. A. Judge (Eds.), The organizational frontiers series. Perspectives on organizational fit (pp.209-258), Mahwah, NJ: Lawrence Erlbaum Associates Publishers.

El-Anzi, F. (2005). Academic achievement and its relationship with anxiety, self-esteem, optimism, and pessimism in Kuwaiti students. Social Behavior and Personality: An International Journal, 33, 95-104. DOI: https://doi.org/10.2224/sbp.2005.33.1.95.

Etzel, J. M., \& Nagy, G. (2016). Students' perceptions of person-environment fit: Do fit perceptions predict academic success beyond personality traits? Journal of Career Assessment, 24(2), 270-288. http://dx.doi.org/10.1177/1069072715580325.

Gilani, N., Waheed, S. A., Saleem, K., \& Shoukat, L. (2015). Do emotions affect academic achievement in adulthood? Relationship between postgraduate students' trait emotional intelligence and achievement. The AYER, 2, 37-44.

Good, I. J. (1959). Randomised and pseudorandomised substantialization of sign sequences. Acta Crystallographica, 12(10), 824-825.

Hoegl, M., \& Parboteeah, K. P. (2003). Goal setting and team performance in innovative projects: On the moderating role of teamwork quality. Small Group Research, 34(1), 3-19. http://dx.doi.org/10.1177/1046496402239575.

House, R., \& Rizzo, J. (1972). Role conflict and ambiguity as critical variables in a model of organizational behavior. Organizational Behavior and Human Performance, 7 ,
467-505.

Huppert, F. A., \& Whittington, J. E. (2003). Evidence for the independence of positive and negative well-being: Implications for quality of life assessment. British Journal of Health Psychology, 8(1), 107-122. doi:10.1348/135910703762879246

Jarkowski, S. (2011). Social skills and learning success in cooperative learning. Kassel, Germany: Kassel University Press.

Jung, C. S. (2011). Organizational goal ambiguity and performance: Conceptualization, measurement, and relationships. International Public Management Journal, 14(2), 193-217.

Kristof-Brown, A. L., Zimmerman, R. D., \& Johnson, E. C. (2005). Consequences of individuals' fit at work: A meta-analysis of person-job, person-organization, person-group, and person-supervisor fit. Personnel Psychology, 58(2), 281-342.

Keefer, K. V., Parker, J. D. A., \& Saklofske, D. H. (2018). Emotional intelligence in education. Integrating research with practice. Cham, Switzerland: Springer.

Keyes, C. L. M., Shmotkin, D., \& Ryff, C. D. (2002). Optimizing well-being: The empirical encounter of two traditions. Journal of Personality and Social Psychology, 82(6), 1007-1022.doi:10.1037/00223514.82.6.1007.

Kirby, K. N., \& Herrnstein, R. J. (1995). Preference reversals due to myopic discounting of delayed reward. Psychological Science, 6(2), 83-89. doi.org/10.1111/j.1467-9280.1995.tb00311.x.

Knouse, K. A., Wu, J., \& Amon, A. (2014). Assessment of megabase-scale somatic copy number variation using single-cell sequencing. Genome Research, 26(3), 376384. doi: $10.1101 /$ gr. 198937.115

Kuncel, N. R., Hezlett, S. A., \& Ones, D. S. (2004). Academic performance, career potential, creativity, and job performance: Can one construct predict them all? Journal of Personality and Social Psychology, 86(1), 148-161.

Kyndt, E., Raes, E., Lismont, B., \& Timmers, F. (2014). A meta-analysis of the effects of face-to-face cooperative learning. Do recent studies falsify or verify earlier findings? Educational Research Review, 10, 133-149. DOI: 10.1016/j.edurev.2013.02.002.

Latham, G. P., \& Locke, E. A. (1991). Self-regulation through goal setting. Organizational Behavior and Human Decision Processes, 50(2), 212-247. http://dx.doi.org/10.1016/0749-5978(91)90021-K

Latham, G. P., \& Locke, E. A., (2013). New developments in goal setting and task performance. New York, NY: Routledge/Taylor \& Francis Group.

Latham, G. P., Borgogni, L., \& Petitta, L. (2008). Goal setting and performance management in the public sector. International Public Management Journal, 11, 385-403.

Leedy, P. D., \& Ormrod, J. E. (2005). Practical research: Planning and design. Upper Saddle River, NJ: Prentice Hall. 
Leech, N. L., Barret, K. C. \& Morgan, G. A. (2005). SPSS for introductory statistics: Use and intermediate (2nd Ed.). New Jersey: Lawrance Erlbaum Associates Inc.

Locke, E. A., \& Latham, G. P. (2002). Building a practically useful theory of goal setting and task motivation: A 35year odyssey. American Psychologist, 57, 705-717. doi:10.1037/0003-066X.57.9.705.

Matthews, G., Zeidner, M., \& Roberts, R. (2004). Emotional intelligence in the workplace: A critical review. Applied Psychology, 33, 371-399. http://dx.doi.org/10.1111/j.1464-0597.2004.00176.x.

Mayer, J. D., Salovey, P., \& Caruso, D. R. (2000). Models of emotional intelligence. In R. Sternberg (ed.), Handbook of intelligence (pp.396-420), Cambridge, UK: Cambridge University Press. Doi:10.1017/CBO9780511807947.019

Mayer, J. D., Salovey, P., \& Caruso, D. R. (2004). Emotional intelligence: Theory, findings, and implications. Psychological Inquiry, 15, 197-215. doi.org/10.1207/s15327965pli1503_02.

McDowell, L. (2010). Capital culture revisited: Sex, testosterone and the city. International Journal of Urban and Regional Research, 34(3), 652658. doi:10.1111/j.1468-2427.2010.00972.x.

Minnaert, A., \& Janssen, P. J. (1998). The additive effect of regulatory activities on top of intelligence in relation to academic performance in higher education. Learning and Instruction, 9(1), 77-91. DOI: 10.1016/S09594752(98)00019-X.

Mischel, W., Shoda, Y., \& Rodriguez, M. (1989). Delay of gratification in children. Science, 244(4907), 933938. doi:10.1126/science.2658056.

Nasir, M., \& Masrur, R. (2010). An exploration of emotional intelligence of the students of IIUI in relation to gender, age and academic achievement. Bulletin of Education and Research, 32(1), 37-51.

Nelson, K. J., Quinn, C., Marrington, A., \& Clarke, J. A. (2012). Good practice for enhancing the engagement and success of commencing students. Higher Education, 63(1), 83-96.

Ostrove, J., \& Long, S. M. (2007). Social class and belonging: Implications for college adjustment. The Review of Higher Education, 30(4), 363-389. DOI: 10.1353/rhe.2007.0028.

Pandey, S. K., \& Rainey, H. G. (2006). Public managers' perceptions of organizational goal ambiguity: Analyzing alternative models. International Public Management Journal, $\quad 9(2), \quad 85-112 . \quad$ DOI: 10.1080/10967490600766953.

Parker, J. D. A., Summerfeldt, L. J., Hogan, M. J., \& Majeski, S. (2004). Emotional intelligence and academic success: Examining the transition from high school to university. Personality and Individual Differences, 36, 163-172.

Perera, H., \& Digiacomo, M. (2015). The role of trait emotional intelligence in academic performance during the university transition: An integrative model of mediation via social support, coping and adjustment. Personality and Individual Differences, 83, 208-213. DOI: 10.1016/j.paid.2015.04.001

Petrides, K., Frederickson, N., \& Furnham, A. (2004). The role of trait emotional intelligence in academic performance and deviant behavior at school. Personality and Individual Differences, 36, 277-293.

Pittman, L. D., \& Richmond, A. (2007). Academic and psychological functioning in late adolescence: The importance of school belonging. Journal of Experimental Education, 75(4), 270-290. http://dx.doi.org/10.3200/JEXE.75.4.270-292.

Plant, E. A., Ericsson, K. A., Hill, L., \& Asberg, K. (2005). Why study time does not predict grade point average across college students? Implications of deliberate practice for academic performance. Contemporary Educational Psychology, 30(1), 96-116. doi:10.1016/j.cedpsych.2004.06.001.

Plutchik, R. (1987). Evolutionary bases of empathy. In N. Eisenberg, \& J. Strayer (Eds.), Cambridge studies in social and emotional development. Empathy and its development (pp.38-46), New York, NY: Cambridge University Press.

Rainey, H. G., \& Jung, C. S. (2014). A conceptual framework for analysis of goal ambiguity in public organizations. Journal of Public Administration Research and Theory, 25(1), 71-99.

Richardson, M., Abraham, C., \& Bond, R. (2012). Psychological correlates of university students' academic performance: A systematic review and metaanalysis. Psychological Bulletin, 138(2), 353-387. doi:10.1037/a0026838.

Rozell, E. J., Pettijohn, C. E., \& Parker, R. S. (2002). An empirical evaluation of emotional intelligence: The impact on management development, Journal of Management Development, 21(4), 272-289.

Ryan, R. M., \& Deci, E. L. (2001). On happiness and human potentials: A review of research on hedonic and eudaimonic well-being. Annual Review of Psychology, 52(1), 141-166. doi:10.1146/annurev.psych.52.1.141.

Ryff, C. D., Singer, B. H., \& Love, G. D. (2004). Positive health: Connecting well-being with biology. Philosophical Transactions of the Royal Society of London B, 359, 1383-1394.

Sawyer, J. E. (1992). Goal and process clarity: Specification of multiple constructs of role ambiguity and a structural equation model of their antecedents and consequences. Journal of Applied Psychology, 77(2), 30-142. DOI: 10.1037/0021-9010.77.2.130.

Salovey, P., \& Mayer, J. D. (1990). Emotional intelligence. Imagination, Cognition \& Personality, 9(3), 185-211.

Schutte, N. S., Malouff, J. M., Hall, L. E., Haggerty, D. J., Copper, J. T., Golden, C. J., \& Dornheim, L. (1998). Development and validation of a measure of emotional intelligence. Personality and Individual Differences, 25, 167-177.

Schmitt, D., Realo, A., Voracek, Martin, A. J. (2008). Why 
can't a man be more like a woman? Sex differences in big five personality traits across 55 cultures. Journal of Personality and Social Psychology, 94(1), 168-182. DOI: 10.1037/a0014651.

Severiens, S., Wolff, R., \& Herpen, S. V. (2015). Teaching for diversity: A literature overview and an analysis of the curriculum of a teacher training college. European Journal of Teacher Education, 37(3), 295-311. DOI: 10.1080/02619768.2013.845166.

Shipley, N. L., Jackson, M. J., \& Segrest, S. L. (2010). The effects of emotional intelligence, age, work experience, and academic performance. Research in Higher Education Journal, 9, 1-18.

Stewart, S. B. (2015). Grit and self-control as predictors of first-year student success. Doctorial dissertation. Retrieved August 30, 2019 from http://digitalcommons.usm.maine.edu/cgi/viewcontent.c gi? article $=1172 \&$ context $=$ etd.

Stoeber, J., \& Rambow, A. (2007). Perfectionism in adolescent school students: Relations with motivation, achievement, and well-being. Personality and Individual Differences, 42(7), 1379-1389.

Tracey, T. J. G., \& Robbins, S. B. (2006). The interest-major congruence and college success relation: A longitudinal study. Journal of Vocational Behavior, 69(1), 64-89. http://dx.doi.org/10.1016/j.jvb.2005.11.003.

Trapmann, S., Hell, B., Hirn, J. O. W., \& Schuler, H. (2007). Meta-analysis of the relationship between the big five and academic success at university. Z. Psychol. [J. Psychol.], 215, 132-151. 10.1027/0044-3409.215.2.132.

Tynjälä, P. (2008). Perspective into learning in the workplace. Educational Research Review, 3(2), 130-154. DOI: 10.1016/j.edurev.2007.12.001.

Vela Jr., R. H. (2003). The role of emotional intelli-gence in the academic achievement of first year college students. Doctorial dissertation. Kingsville, TX: Texas A\&M University.
Vermunt, J. D., \& Endedijk, M. D. (2011). Patterns in teacher learning in different phases of the professional career. Learning and individual differences, 21(3), 294302. https://doi.org/10.1016/j.lindif.2010.11.019.

Vermunt, J. D., Richardson, J. T., Donche, V., \& Gijbels, D. (2014). Students' learning patterns in higher education. Dimensions, measurement and change. In D. Gijbels, V. Donche, J. T. Richardson, \& J. D. Vermunt (Eds.), Learning patterns in higher education. Dimensions and research perspectives (pp.295-310), London: Routledge.

Wessel, J. L., Ryan, A. M., \& Oswald, F. L. (2008). The relationship between objective and perceived fit with academic major, adaptability and major related outcomes. Journal of Vocational Behavior, 72, 363-376.

West, M. A., \& Anderson, N. R. (1996). Innovation in top management teams. Journal of Applied Psychology, 81(6), 680-693. DOI: 10.1037/0021-9010.81.6.680.

Woitaszewski, S. A., \& Aalsma, M. (2004). The contribution of emotional intelligence to the social and academic success of gifted adolescents as measured by the Multifactor Emotional Intelligence Scale: Adolescent version. Roeper Review, 27(1), 25-30. DOI: $10.1080 / 02783190409554285$.

Wolters, C. A. (2003). Understanding procrastination from a self-regulated learning perspective. Journal of Educational Psychology, 95(1), 179-187. http://dx.doi.org/10.1037/0022-0663.95.1.179.

Wright, B. E. (2004). The role of work context in work motivation: A public sector application of goal and social cognition theories. Journal of Public Administration Research and Theory, 14(1), 59-78.

Zimmerman, B. J. (2008). Investigating self-regulation and motivation: Historical background, methodological developments, and future prospects. American Educational Research Journal, 45(1), 166-183. http://dx.doi.org/10.3102/0002831207312909. 